\title{
Use and occupation of soil and carcinoculture in the ciliar forest of the Paraíba do Norte river in municipality of Mogeiro/PB, Brazil
}

The environmental collapse has required an enormous effort to guarantee studies that contribute to planetary environmental conservation. Diametrically, the riparian forest has suffered a great loss of vegetation biome to the detriment of human occupation in these ecosystems. Currently, in the face of the global environmental crisis, riparian forests have been the most degraded ecosystem on the planet. In another sense, riparian forests play an indispensable role in maintaining aquatic and terrestrial environments. Work aims to map the uses and occupations of the soil in riparian forest areas of the Paraíba do Norte River, in

Mogeiro - PB. To this end, the research methodology consists of characterizing the use and occupation using remote sensing and delimitation of images to create marginal strips of the 50-meter perennial natural water course in line with the Forest Code (12651/12).

Keywords: Collapse; Ecosystem; Caatinga; Territory.

\section{Uso e ocupação do solo e carcinocultura na mata ciliar do rio Paraíba do Norte no município de Mogeiro/PB, Brasil}

\begin{abstract}
O colapso ambiental tem exigido um enorme esforço para garantir estudos que contribuam para a conservação ambiental planetária. Diametralmente, a mata ciliar tem sofrido uma grande perda de bioma vegetal em detrimento da ocupação humana nesses ecossistemas. Atualmente, em face da crise ambiental global, as matas ciliares têm sido o ecossistema mais degradado do planeta. Em outro sentido, as matas ciliares desempenham um papel indispensável na manutenção dos ambientes aquáticos e terrestres. O trabalho visa mapear os usos e ocupações do solo em áreas de mata ciliar do rio Paraíba do Norte, em Mogeiro - PB. Para tanto, a metodologia de pesquisa consiste em caracterizar o uso e ocupação por sensoriamento remoto e delimitação de imagens para a criação de faixas marginais de curso d'água natural perene de 50 metros em consonância com o Código Florestal (12651/12).
\end{abstract}

Palavras-chave: Collapse; Ecossistema; Caatinga; Território.

Topic: Desenvolvimento, Sustentabilidade e Meio Ambiente

Reviewed anonymously in the process of blind peer.
Received: $11 / 11 / 2020$ Approved: 09/02/2021
Luís Pedro Do Nascimento Souza (iD

Universidade Federal de Campina Grande, Brasil

http://lattes.cnpq.br/0817862532002813

http://orcid.org/0000-0002-6314-7179

luispedro15@hotmail.com

Debora Coelho Moura (it)

Universidade Federal de Campina Grande, Brasil

http://lattes.cnpq.br/4114902987951934

http://orcid.org/0000-0003-2663-2308

debigeo1@hotmail.com

Ailson De Lima Marques (iD

Universidade Federal da Paraíba, Brasil

http://lattes.cnpq.br/7731519684534647

http://orcid.org/0000-0002-6838-275X

marque.ailsonl@gmail.com
Cássio Ricardo Gonçalves da Costa (iD)

Universidade Federal Rural do Semiárido, Brasil

http://lattes.cnpq.br/2792104584823593

http://orcid.org/0000-0003-4207-342X

cassioagronomoufpb@gmail.com
Referencing this:

SOUZA, L. P. N.; MOURA, D. C.; MARQUES, A. L.; COSTA, C. R. G.. Use and occupation of soil and carcinoculture in the ciliar forest of the Paraíba do Norte river in municipality of Mogeiro/PB, Brazil. Natural Resources, v.11, n.1, p.102-109, 2021. DOI:

http://doi.org/10.6008/CBPC2237-9290.2021.001.0013 


\section{INTRODUCTION}

Human occupation in the Northeastern Semi-Arid is considered to be one of the largest in the world. Almost 22 million inhabitants live in this region. In Paraíba, 86\% of its territory is within the Brazilian semiarid area, where more than 2 million paraibanos live. This scenario and the multiple forms of human occupation have represented enormous pressures on local biodiversity (RAMALHO, 2013; MACIEL et al., 2015).

In this region, water resources enhance human occupation. However, in the past, the strong sugar economy devastated the riparian zones of the Paraíba do Norte River (ANDRADE, 2005). As well as, at present, these areas are being occupied by several economic enterprises, in which shrimp farming stands out.

The production of shrimp in captivity in the municipality of Mogeiro (low course of the Paraíba river) emerged in 2009 in the riparian zones of the river, as an alternative to the agricultural decline due to soil exhaustion.

In this context, it is a problematic activity, since the riparian forest areas are areas of notorious merit of preservation. In articles 3 and 4, items II and I, respectively, the New Forest Code establishes that APP (Permanent Preservation Area) is a protected area due to its great biological value, and also defines that all marginal strips of rural rivers or urban, with perennial, intermittent or ephemeral drainage must be protected by riparian forests with a length of at least 30 to 500 meters, depending on the width of the river channel (BRASIL, 2012).

In this context, the present work is justified by the need to investigate the occupation of marginal areas of the RPN, of which agricultural enterprises, shrimp production, stand out. As well as the multiple uses and occupations of the soil in riparian areas of the Paraíba do Norte River, in Mogeiro - PB. It is intended to provide a technical argument that contributes to the recovery of local biodiversity.

Thus, this research aims to improve the uses and occupations of the soil in the course of the Paraíba do Norte River - PB in the municipality of Mogeiro-PB, characterizing the Permanent Preservation Area and the production of shrimp in captivity.

\section{MATERIALS AND METHODS}

The study was carried out in the municipality of Mogeiro, in the state of Paraíba - PB (Figure 1). The municipality is located in the Mesoregion of Agreste Paraibano, under the geographical coordinates $7^{\circ} 18$ '02.88 "S and $35^{\circ} 28^{\prime} 38.05^{\prime \prime} \mathrm{O}$. The referent municipality is on an altitude of $118 \mathrm{~m}, 103 \mathrm{~km}$ distant from the capital from Paraíba, João Pessoa, occupying a total area of 219 km (BRASIL, 2005; IBGE, 2017).

The municipality stands out for its location on the domain of the Planalto da Borborema Province. The municipality is located in the eastern domain of the province, formed by ancient lands, with different lithologies of the granitoid complex of the crystalline basement of the Cariris Velhos, which makes up an area of $80 \%$ of the territory of Paraíba (BRASIL, 2005; MAIA et al., 2014). 


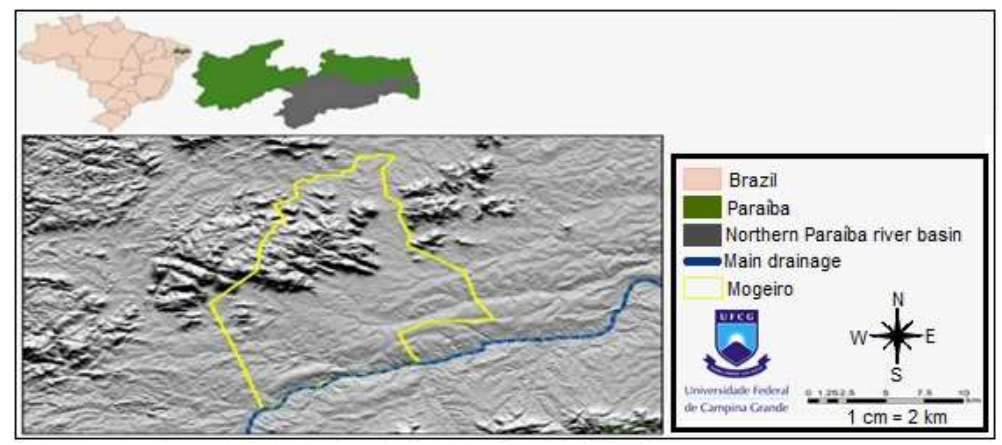

Figure 1: location map of the municipality of Mogeiro -PB.

The municipality is located at the foot of the Planalto da Borborema, a geostructural formation typical of the Northeastern Semi-arid, characterized by a pediplanation surface, with residual relief, with wavysmooth physiognomy, with encrusted valleys, flattened slopes and ridges, geostructural compartments typical of northern area of the Borborema Plateau (BRASIL, 2005; CORRÊA et al., 2010).

According to Corrêa et al. (2010) the semi-arid climate covers the area. However, the rainfall regime is characterized by the autumn-winter distribution, characteristic of the eastern edge of the Borborema Plateau, as well as the atmospheric effects that suffer from the edge of the South American Eastern Platform, precipitation varies from 400 to $600 \mathrm{~mm}$ annually, temperature above $27^{\circ} \mathrm{C}$, with more than 2500 hours of sunshine per year.

There are gneisses and migmatites (outcrops) directly on the surface and where the drainage fits, exposing dissected Platforms and Strands. The exposure of the mantle of alteration of rocks, slabs, outcrops and detrital pavements is justified, which are accentuated with the largest rainfall regimes, such as torrential rainfall in the rainy season (CORRÊA et al., 2010; MAIA et al., 2014).

According to EMBRAPA (2005) and EMBRAPA (2006), pedology in the area varies in Planassolos, noncalcium soils, Argisols, Litolic Neossols and Fluvic Neossols. In this area, there is a phytophionomy of the Caatinga Biome, hyperxerophilic in the stony and dissected terrains and hypoxerophilic Caatinga, in the areas of the humid slopes and valleys of the municipality.

The increasing pace of shrimp production in the municipality is a consequence of the increase in shrimp production in the Northeast Region. In 2014 , $90 \%$ of the shrimp farming activities were in the Northeast of Brazil, as a result of the internalization of production in tanks, that is, intensive production to replace the extensive production practiced, mostly, on the coast, especially in estuarine areas.

Shrimp farming is produced in the municipalities of Mogeiro, Salgado de São Félix and Itabaiana, which are bathed by the waters of Paraíba do Norte. Shrimp production stands out in the municipality of Mogeiro due to the opening of the ice factory in 2009. But it was from 2013 that the shrimp farming activity gained national notability (SILVEIRA et al., 2011; BANDEIRA, 2016).

\section{Procedural steps}

The geoprocessing computer program ARCGIS 10.5 (Georeferenced Information Processing System) was used, under its own license, where the Geographic Database (BDG) was created, stored, manipulated 
and managed and the image processing and algebra functions were performed of maps.

Expeditious field trips were made, analyzing and evaluating the different uses and the conservation status of the Basin, providing an overview of the current use and allowing the identification of areas of greatest anthropic pressure.

The Land Use and Vegetation Cover map was prepared by the interpretative analysis of images from the Landsat 8 satellite, referring to the orbit point 214/65, using an image from May 2018. To facilitate target discrimination, pre-processing was carried out of the image (contrast expansion) and worked with R4G3B2 real color compositions. Since these colored compositions helped to identify the different uses and land cover that followed the taxonomy of the new methodology of IBGE (2015), based on the Rural Environmental Registry.

Then, the classification supervised by Maxver similarity was carried out. After this mapping, the vector editing tool was used to correct areas with errors and include unclassified polygons. The classes identified for this mapping were: Consolidated area, which refers to all consolidated human uses until 2012 (Forest Code); Forest Area, which refers to all areas of native forest that cannot be changed; and Legal Reserve, which refers to all forest areas in various successional stages that are being maintained for land adaptation to the Forest Code.

\section{Delimitation of the permanent preservation área}

In compliance with Article 2 of Federal Law No. 4,771 / 65 of the Brazilian Forest Code and CONAMA Resolutions No. 302/02 and No. 303/02, the APPs map was generated, however as a simulation, since all riparian areas were already consolidated before 2012.

To obtain the APP map, we initially worked with the drainage network map of the study area, obtained from the topographical maps of IBGE, in digital format, scale 1: 50,000, on the SIRGAS 2000 datum.

The APPs of springs, dams and rivers were obtained by generating maps of distances or buffers. For this, the buffer module of ARCGIS 10.5 was used, initially generating a rectangular grid with distance values (numerical model) of water courses and dams (line type vectors) and springs (point type vectors). After that, they were sliced for the creation of APPs protected by law, as shown in (Table 1).

Table 1: Marginal bands for aquatic environments.

\begin{tabular}{l|l}
\hline Feature & Riparian Forest Range (Buffer function) \\
\hline Watercourses represented by double margin $(10 \leq$ width $\leq 30 \mathrm{~m})$ & $50 \mathrm{~m}$ on each bank \\
\hline Water courses represented by simple lines (width $\leq 10 \mathrm{~m})$ & $30 \mathrm{~m}$ on each bank \\
\hline Artificial reservoirs in rural areas with a surface area $\geq 20 \mathrm{ha}$ & $100 \mathrm{~m}$ around the reservoir \\
\hline Artificial reservoirs in rural areas with surface area $<20 \mathrm{ha}$ & $50 \mathrm{~m}$ around the reservoir \\
\hline Springs & $50 \mathrm{~m}$ radius \\
\hline Slopes & Declivity greater than 45ㅇ \\
\hline
\end{tabular}

Source: BRASIL (2012).

\section{RESULTS AND DISCUSSION}

\section{Current land uses and occupations}

When analyzing land use and occupation, it can be noted that these are characterized by three 
patterns of spatial organization. All patterns are correlated with the suitability Register Am environ mental Rural (CAR) with month data May 2018. Therefore uses three classes (Figure 2, A, B and C) consolidated area (182 square kilometers), Forest Area $\left(17 \mathrm{~km}^{2}\right)$ and Legal Reserve $\left(15 \mathrm{~km}^{2}\right)$ (Figure $3, \mathrm{~A}, \mathrm{~B}$ and $\mathrm{C}$ ).

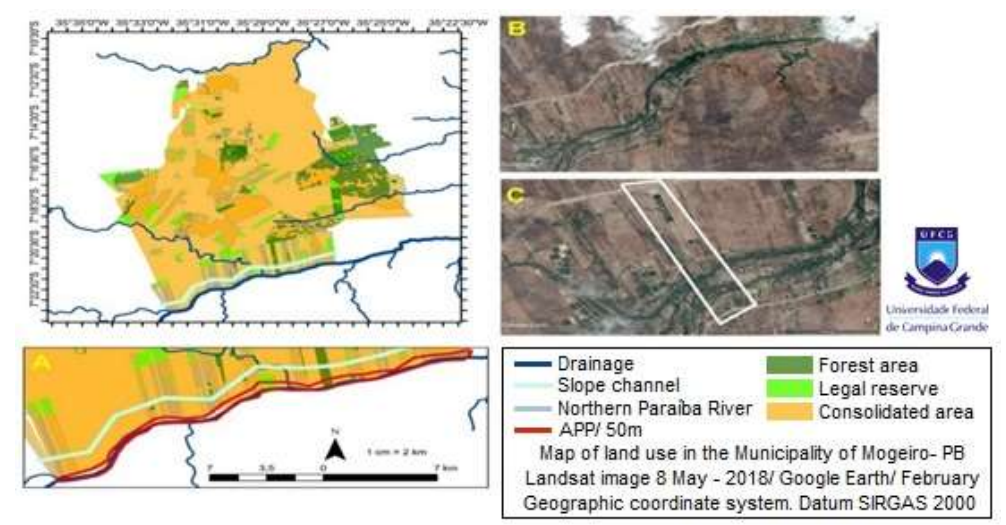

Figure 2: Map of distribution of land use classes in the municipality of Mogeiro - PB. A) Buffer from the Permanent Preservation Area; B) Panoramic view of the APP's; and C) Longitudinal distribution of farms in APP's.

In this context, as observed, the greatest territorial dominance is Consolidated Area. As observable in the field, the area in question is embedded in the Brazilian northeastern interior, and had its development based on European religious missions and cattle raising. Currently, these transformations in space have left traces and changes in the territory that persist and shape the current landscape.

Diametrically, it is noted in the field that the occupation of the area occurred in line with the urban occupation that occurred in the semi-arid region, close to the water bodies, taking advantage of the river plains and the main courses of the hydrographic basins. As a result, the first settlements emerged, such as Dois Riachos, having their origin at the end of the 18th century, which corroborate the evidence of the occupation of the aforementioned area.

It was noticed, therefore, that the first urban centers and farms were consolidated in the floodplain areas, generating conflicts between the local ecosystems, riparian forest, in particular, and the disorderly occupation over it. It is noted that the headquarters of the farms are consolidated close to the main drainage network, a longitudinal consolidation of the properties, that is, from the floodplains to the steeper areas of the river slopes.

The interior areas of the Northeast Region are needy areas, most of the inhabitants are assisted by the benefits of the Federa Government and the municipalities are supported by the FPM Municipality Participation Fund. It appears that another limiting factor for the production of irrigated agriculture is the soil conditions, with little developed and acidic horizons.

Vasconcelos Sobrinho (1978) emphasizes that the soils of these northeastern areas are limited and conditioned by an unstable ecological balance, due to rainfall conditions, fluctuations in rainfall patterns, generally decreased during the year, Neossols, Regolitic and Litholic subclasses, with a poorly developed horizon, with limited water retention, high insulation, dry and hot winds result in soil dehydration.

Above all, it was found that the soils in the study area are conducive to the concentration of salts on the surface and the waters that are used for irrigation have high levels of total dissolved salts, which provides 
the concentration of salts in the soil. In these geoenvironmental conditions, precautions are necessary in the management of the soil of the areas, avoiding practices and cultures that are harmful to the soils.

Finally, it is observed in the field that the last economic cycle of the study area, fish farming. That started with the expropriation of a property with more than 100 ha, for 20 squatters, of which each acquired a tank for the production of black tilapia.

That due to the drought that the Brazilian Northeast was going through in the early 2000s, production soon succumbed. In surveys carried out by Silveira et al. (2011) they mention that shrimp farming activities are returning due to the inauguration of the ice factory, at Sítio Areial, in the municipality of Mogeiro, providing security for producers in the expenditure on tanks.

\title{
The occupation of the riparian forest área
}

Two fragments of riparian forest were recorded in the $50 \mathrm{~m}$ perimeter of the river. The first fragment (light green) (Figure 3) is undergoing ecological regeneration. Much of the conserved area belongs to Fazenda São João, which has no agricultural function, which existed in the past. This was the only large farm, which did not adhere to shrimp production.

The second fragment (dark green) (Figure 3), is an area with conserved vegetation, with arboreal vegetation, with Neolithic Regolithic and rocky outcrops, showing that the soils have no contribution for the location of the shrimp tanks.

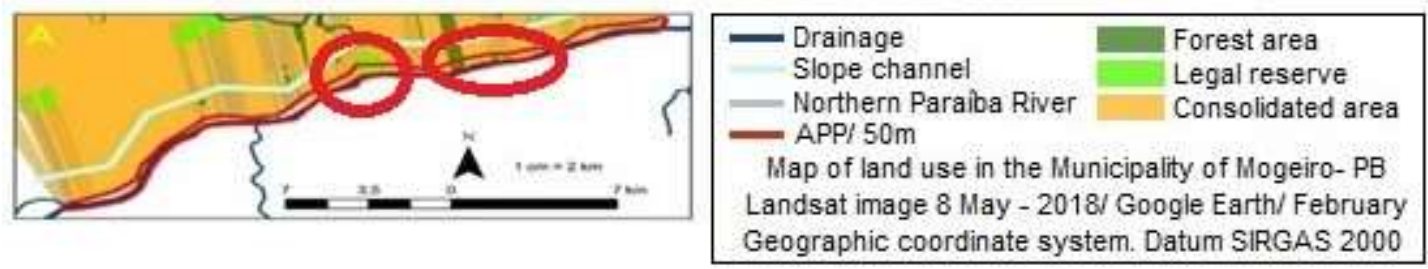

Figure 3: Map of land use and occupation in the area under analysis, highlighting the Permanent Preservation Area (APP), on the Paraíba do Norte River, in Mogeiro - PB.

Thus, it appears that the forest fragments are fragmented and isolated due to intense exploitation.

The two conserved areas were conditioned by environmental factors, not as a result of the restriction on use and by encouraging the conservation of the area. For Schaadt et al. (2015):

\begin{abstract}
Forest fragmentation is a process in which continuous forests are divided into smaller fragments and isolated in a different matrix from the original habitat. The isolation caused by fragmentation exposes the remnants to different climatic conditions, such as reduced air humidity and increased light and temperature, in addition to greater exposure to winds, resulting in a decline in the number of species in the remnant (DELAMÔNICA et al., 2001; PIRES et al., 2002). The reduction and isolation of species populations hamper the gene flow, which can cause loss of biodiversity and even the extinction of species (BRITEZ et al., 2003). For this reason, forest fragmentation is considered one of the factors with the greatest impact on biodiversity conservation (LAURANCE et al., 1997). (...) The biotic and abiotic changes that occur mainly at the edge of fragments, called edge effects, influence the structure of vegetation and animal communities.
\end{abstract}

We observe the soils of alluvial origins, of which the most found in the area form the Fluvic Neossols. These are composed by the horizon $\mathrm{O}$, with organic matter, $20 \mathrm{~cm}$ thick, not showing the horizon $\mathrm{B}$, with pale 
to mottled, occupy areas of the marginal dykes until the most distant part of the river terrace, with depths that vary from few centimeters to a few meters. In this regard, the inappropriate activities and uses close to the hydrographic basins, increase the debris load to the river, in the area in question the tanks are spatialized over the Fluvic Neossols. The authors show that

The retention of solids (silting) in flood plains and associated rivers is also a major concern. The geomorphological modifications of the floodplain can influence its biological productivity, determining a change in the patterns of fishing productivity of the entire hydrographic basin, in addition to interfering in transport and in the flood pattern (SANTOS, 2002).

In line with the studies by Silva et al. (2012), these types of soil are present in lowland areas, on river terraces, few drained and showing high fertility. Thus, the areas composed by Entisols, areas of riparian forest, are the largest number of shrimp tanks, as well as few "ponds" for the purification of effluents from the expenditure of the product in the tanks.

It should be noted that the location of the smaller bed favors the spatialization, in most cases, of shrimp breeding tanks. Therefore, its location close to the water catchment areas, lead the creators to reduce with electrical material and PVC pipes to implant the breeding tanks.

Therefore, it is necessary that planning in the basin in question take into account aspects of river sedimentation, as well as occupation processes in the area. The environmental impacts in the Paraíba do Norte River Basin (BHRPN) result in an increase in suspended materials, putting at risk the availability of water for human consumption. In this regard Bigarella (1979):

The knowledge of river characteristics is important not only with regard to water resources, both from the point of view of hydraulics and erosion control, but also from the point of view of sedimentology, geomorphology and regional planning.

\section{CONCLUSIONS}

In accordance with the studies by Christofoletti (1980), we show that the alluvial terraces formed in the area lead to the establishment of "paired terraces", with an equal distribution in the river slopes, where the abandonments of the river excavation promoted the appearance of flat and soil areas deep.

It is noticed that the shrimp tanks are mostly in alluvial terraces, with older soil composition, formed by sediments from the old RPN floodplain.

The verticalities of the river terraces condition the appearance of tanks on the site. These are areas that are more distant from the smaller bed, with no constant flooding in winter. Therefore, we note that these areas offer security to producers, as producers would not jeopardize the productivity and structure of the tanks during the harsh winter period.

It appears that the few 'ponds' that exist in the area for the purification of effluents during the period of waste in the farms are close to the marginal dykes and occupy a large part of the largest periodic bed. This is due to the fact that the riverbed in di. 


\section{REFERENCES}

ANDRADE, M. C. O.. The earth and man in the Northeast: contribution to the study of the agrarian question in the Northeast. Cortez publisher, 2005.

BIGARELLA, J.. Fluvial Environment: Sedimentation Environments, their interpretation and importance. Curitiba: Federal University of Paraná, 1979.

BRASIL. National Water Agency. Technical note 045/2010SIP-ANA. Modifications to the existing conditions in the Forest Code Reference: Official Letter 215/2010 / GM / MMA of 17/03/2010. Brasília: National Water Agency, 2010.

BRASIL. Mineral Research and Resources Company. Project register of sources of supply for groundwater. CRPM, 2005.

BRASIL. Ministry of the Environment. Forest Code (12,651/12). Brasília: Ministry of the Environment, 2012.

CORRÊA, A. C. B.; TAVARES, B. A. C.; MONTEIRO, K. A.; CAVALCANTI, L. C. S.; LIRA, D. R.. Megageomorphology and morphosstructure of the borborema planalt. Magazine of the Geological Institute, v.31, p.35-52, 2010.

CHRISTOFOLETTI, A.. Geomorphology. São Paulo: Edgard Blucher, 1980.

EMBRAPA. Brazilian Agricultural Research Corporation. Agroeconomic Aspects of Maize Culture: Characteristics and Evolution of Culture in the State of Paraíba between 1990 and 2003. EMBRAPA, 2005.

EMBRAPA. Brazilian Agricultural Research Corporation. Soil Manual of Brazil. EMBRAPA, 2006.

HADLICH, E. C.. Land use in riparian forest areas in the Hydrographic Basins of the Dona Luiza and Ribeirão Matilde Rivers, in the municipality of Atlanta - SC. Master's (Dissertation in Philosophy and Human Sciences) - Federal University of Santa Catarina, Florianópolis, 2002.
IBGE. Brazilian Institute of Geography and Statistics. Mogeiro: cities. IBGE, 2015.

IBGE. Brazilian Institute of Geography and Statistics. Rural Environmental Registry (CAR). Brazilian Institute of Geography and Statistics, 2017.

MAIA, R.; BEZERRA, R.; FRANCISCO, H.. Structural conditioning of the relief in the Brazilian Northern Nordes. Mercator Magazine, Fortaleza, v.13, n.1, p.127-141, 2014.

MACIEL, C. A. A.; PONTES, E. T. T.. Seca and coexistence with the semiarid: adaptation to the environment and patrimonialization of the Caatinga in Northeast Brazil. Rio de Janeiro: Consequência, 2015.

RAMALHO, M. F.. The environmental fragility of the Brazilian Northeast: the semi-arid climate and the unpredictability of the great droughts. Sociedade e Território magazine, Natal, v.25, n.2, p.104-115, 2013.

SANTOS, M.. The nature of space: techniques and time, reason and emotion. São Paulo: Edusp, 2002.

SCHAADT, S. S.; VIBRANS, A. C.. Land Use in the Surroundings of Forest Fragments Influences its Composition and Structure. Revista Floresta e Ambiente, v.22, n.4, p.437-445, 2015.

SILVA, J. M. O.; SILVA, E. V.. Geo- environmental analysis of the low course of the ráfica hidrog basin of rio Pirangi CE. Revista Geonorte, v.3, n.4, p.593-605, 2012.

SILVEIRA, J. A.; ALMEIDA, A.. Evaluation of fish farming in the region of Mogeiro-PB and the possibilities of development: a study on the Ice Factory. CBT. Inhuma: UAB, 2011.

VASCONCELOS SOBRINHO, J.. Methodology for identifying desertification processes: manual of indicators. Recife: SUDENE, 1978.

A CBPC - Companhia Brasileira de Produção Científica (CNPJ: 11.221.422/0001-03) detém os direitos materiais desta publicação. Os direitos referem-se à publicação do trabalho em qualquer parte do mundo, incluindo os direitos às renovações, expansões e disseminações da contribuição, bem como outros direitos subsidiários. Todos os trabalhos publicados eletronicamente poderão posteriormente ser publicados em coletâneas impressas sob coordenação da Sustenere Publishing, da Companhia Brasileira de Produção Científica e seus parceiros autorizados. Os (as) autores (as) preservam os direitos autorais, mas não têm permissão para a publicação da contribuição em outro meio, impresso ou digital, em português ou em tradução. 